\title{
Sociální reprezentace vyhoření z pohledu vyučujících: „vyhoření“ mezi zkušeností a analytickou kategorií ${ }^{1,2}$
}

\author{
Anna Páchová ${ }^{a}$, Veronika Francováb \\ ${ }^{\text {a,b }}$ Univerzita Karlova v Praze, Pedagogická fakulta, Katedra psychologie
}

Redakci zasláno 20.1. 2019 / upravená verze obdržena 9. 4.2019 /

/ k uveřejnění přijato 11.4. 2019

\begin{abstract}
Abstrakt: Syndrom vyhoření jakožto rizikový faktor pro učitele je zavedený pojem jak ve vědě, tak ve veřejném diskurzu. Co ale pojem vyhoření znamená? Jaký je vztah mezi pojetím vědy a pojetím samotných učitelů? Aby bylo možné na uvedenou otázku odpovědět, je nutné zabývat se obojím - pohledem vědy i pohledem samotných aktérů.

Tato studie se snaží odpovědět na otázku, zda a jakým způsobem se liší vyhoření jakožto sociální reprezentace (pohled vyučujících) a vyhoření jakožto analytická kategorie (akademický diskurz). V úvodní části textu se zabýváme zejména problematikou sociálních reprezentací, následuje popis metod a výsledková část. Srovnání vědecké a aktérské perspektivy je uvedeno $\mathrm{v}$ diskuzi.

Zdrojem dat prezentovaného výzkumného šetření jsou výsledky dotazníku vyhoření $(\mathrm{N}=2394)$, polostrukturované rozhovory s vyučujícími zaměřené na problematiku vyhoření $(\mathrm{N}=46)$ a položky nejužívanějších škál měřících vyhoření.

Výsledky naznačují, že zatímco sociální reprezentace vyučujících se zkušeností s vyhořením má velmi blízko k vědeckému pojetí vyhoření, reprezentace vyučujících bez této zkušenosti je tomuto pojetí vzdálenější. Tito vyučující totiž akcentují zejména vnější rovinu vyhoření ( $\mathrm{z}$ určitého pohledu se tedy zaměřují spíše na důsledky), a to proto, že vnitřní rovina (příčiny vyhoření, tedy vyčerpání) jim zůstává skryta. Článek se zaměřuje rovněž na důsledky, které toto „míjení“ může mít v rovině školní reality.
\end{abstract}

Klíčová slova: vyhoření, sociální reprezentace, vyučující, základní škola

\footnotetext{
Výzkum byl finančně podpořen Českou grantovou agenturou, grant GA16-21302S.

2 Na tomto místě bychom rádi poděkovali doc. PhDr. Vladimíru Chrzovi, Ph.D., za cennou teoretickou inspiraci.
} 


\section{1 Úvod}

Učitelství patří z hlediska míry stresu k jednomu z nejnáročnějších povolání (Johnson et al., 2005; Kebza \& Šolcová, 2003; Žídková \& Martínková, 2003). Mnoho učitelů je kvůli tomu ohroženo syndromem vyhoření (Smetáčková et al., v tisku; Urbanovská, 2011). Z těchto důvodů je problematika učitelského vyhoření důležitým výzkumným problémem. Samotný pojem vyhoření pak aktuálně rezonuje rovněž v současné české společnosti, a ve školství zvlášt'. Co ale pojem vyhoření znamená? Při kladení této otázky vycházíme z předpokladu, že vnější svět nepoznáváme př́mo, ale zprostředkovaně skrze naše smysly a další pojmy užívané v řeči. Ostatně jak již tvrdil Kant, poznaná realita je $\mathrm{v}$ jistém slova smyslu naším vlastním konstruktem, respektive naší vlastní reprezentací (2001). Tento konstrukt ovšem není pouze naším osobním vlastnictvím, ale jelikož vzniká v sociální interakci, má sociální povahu (Bačová, 2000). Sociální a individuální, respektive kulturní a psychické se totiž neustále cirkulárně ovlivňuje (Vybíral, 2001). Cirkulární vliv je možné sledovat rovněž mezi vědeckým a laickým diskurzem. Odpověd' na uvedenou otázku by v tomto smyslu mohla znít: „Jak pro koho.“ Ukazuje se, že výše naznačená otázka je i ve své zdánlivé banálnosti pro náš výzkum naprosto fundamentální. Pokud totiž vztáhneme uvedené východisko na problematiku fenoménu vyhoření, lze konstatovat, že vyhoření je sociálním konstruktem, který se dialekticky pohybuje na ose sociální-individuální, respektive na ose vědecký-laický. $V$ tomto světle je pro porozumění fenoménu vyhoření ve školním prostředí zcela zásadní zjistit, co tento pojem znamená pro samotné aktéry, pro samotné vyučující, a v jakém vztahu je tento význam $\mathrm{k}$ vědeckému významu pojmu vyhoření. Cílem studie je tedy zmapování pomyslného prostoru mezi zkušeností vyhoření a mezi vyhořením jakožto analytickou kategorií.

Jako vhodný teoretický rámec pro prozkoumání uvedených aspektů se jeví teorie sociálních reprezentací (Moscovici, 2000). Tento přístup byl zvolen ze dvou důvodů. Prvním je předpoklad sociálně konstruovaných významů, které jsou rovněž sociálně sdílené, ale současně se mohou v rámci různých kontextů částečně proměňovat (osa sociální-individuální). Druhým důvodem je pak vysvětlující mechanismus přenosu vědeckých významů do laického prostoru a zpět (osa vědecký-laický).

$\mathrm{V}$ následující části textu nejprve pro úplnost stručně popíšeme vědecký význam pojmu vyhoření, který bude jakožto součást empirických zjištění 
podrobněji prezentován ve výsledkové části (4.4). Dále se v rámci úvodní části budeme zabývat teoretickým rámcem sociálních reprezentací. Následovat budou výzkumné otázky a metoda sběru dat. Ve výsledkové části budou nejprve prezentovány kvantitativní data týkající se vztahu mezi subjektivním pocitem vyhoření a jeho měřitelným ekvivalentem (oddíl 4.1). Následně popíšeme obecný model vyhoření z pohledu vyučujících a tematické oblasti, které byly identifikovány v rozhovorech s vyučujícími (4.2), a provedeme porovnání mezi vyučujícími s různou mírou zkušenosti s vyhořením (4.3) V další části se budeme zabývat obsahovou analýzou nejpoužívanějších škál vyhoření (4.4), jejíž výsledek porovnáme s modely vzniklými v oddíle 4.2 (oddíl 5).

\subsection{Pojem vyhoření}

Vyhoření je nejčastěji definováno jako „syndrom emočního vyčerpání, odcizení a poklesu výkonnosti u lidí zaměstnaných v pomáhajících profesích“ (Maslach, 1981, s. 3). Jedná se o důsledek dlouhodobého a nepřiměřeného stresu (Marek, Schaufeli, \& Maslach, 2017), který vede k pocitu fyzického, emočního a kognitivního vyčerpání (Shirom \& Melamed, 2006). Blíže se konceptualizací vyhoření budeme zabývat ve výsledkové části, kde se zaměříme na vybrané škály (včetně jejich teoretických východisek), které jsou užívány k měření vyhoření. Domníváme se totiž, že se tak můžeme nejvíce přiblížit k tomu, jaký je skutečný význam vyhoření ve vědeckém diskurzu. Kristensen a kolegové (2005) kritizují za klasický operacionalistický pozitivismus nejznámější škálu vyhoření (Maslach Burnout Inventory; MBI). Domnívají se, že se točí v kruhu - škála měří to, co je vyhoření, a vyhoření je to, co měří škála. S určitou mírou nadsázky však uvedená kritika platí i pro vztah mezi ostatními modely a škálami. Vyhoření je vlastě tím, co je jednotlivými škálami měřeno. To platí přinejmenším pro studie, které škály využívají. At' se studie hlásí $\mathrm{k}$ jakémukoliv modelu, za vyhoření považují to, co škály měří. ${ }^{3} \mathrm{~V}$ perspektivě sociálního konstruktivizmu samotné škály v podstatě spoluvytvářejí vyhoření jako takové.

\subsection{Teorie sociálních reprezentací}

Autorem teorie sociálních reprezentací je S. Moscovici, který ve svých úvahách navazuje na Durkheimův koncept kolektivních reprezentací. Na rozdíl

Z tohoto důvodu považujeme za nadbytečné bližší představení modelů vyhoření v úvodní části. 
od něj ale vidí reprezentace dynamičtěji a zajímá se hlouběji o jejich strukturu. Sociální reprezentace lze dle Moscoviciho považovat za soubor laického vědění (common sense, Moscovici, 2000). Jsou „fenoménem, který je úzce svázán s konkrétním způsobem porozumění a komunikace a který na jedné straně vytvář́ common sense a na druhé straně realitu" (Moscovici, 2000, s. 33). Každá sociální reprezentace má dva aspekty - ikonický a symbolický. Pro lepší pochopení uvedených aspektů Moscovici uvádí př́́klad z oblasti psychoanalýzy. Např. přídavné jméno „neurotický“ má dle Moscoviciho jak symbolický význam - je to idea, která je spojena s psychoanalýzou a se jménem S. Freuda, tak rovněž ikonický význam - představa neurotika jako někoho, kdo nemá vyřešený oidipský komplex (tamtéž, s. 32).

Sociální reprezentace vznikají v rámci interindividuální komunikace, pomáhají vytvářet a udržovat znalosti a umožňují transformaci abstraktních vědeckých poznatků do podoby common sense (Moscovici, 1981). Vznik sociálních reprezentací se děje pomocí dvou mechanismů - zakotvování a objektifikace. Mechanismus zakotvování dosazuje neznámou ideu do prostoru, který je nám známý (je naším paradigmatem), a tím umožňuje její klasifikaci a pojmenování. Mechanismus objektifikace materializuje abstrakci tak, aby byla srozumitelnější (např. výše zmíněná představa neurotika; Moscovici, 2000). $\mathrm{V}$ průběhu objektifikace vlastně dochází $\mathrm{k}$ tomu, že původní pomocná metafora (např. prostorové zobrazení vědomí a nevědomí) se sama stává realitou (Šimeček, 2008). „Rozdíl mezi reprezentací a tím, co je reprezentováno, je smazán." (Šimeček, 2008, s. 19).

Sociální reprezentace jsou organizované do centrálního jádra a elementů periférie. Zatímco jádro je stabilní a nezávislé na aktuálním kontextu (závislé je na historických, sociologických a ideologických podmínkách), elementy periférie reprezentace jsou na aktuálním kontextu závislé, a jsou tedy také méně stálé, zato pružnější (Kouřilová, 2009). Centrální jádro je hlavní součástí sociální reprezentace - je nositelem jejího významu a je zodpovědné za časovou stálost a homogenitu mezi těmi, kdo reprezentaci sdílejí. Současně rovněž určuje její strukturu. Periferní elementy jsou tedy na jádru závislé. Současně jsou ovšem zodpovědné za zakotvenost sociální reprezentace v různých sociálních realitách. Tím zprostředkovávají její různost (Arbic, 1993, in Kouřilová, 2009). Dle Nováka (2009) je základem kvalitativního výzkumu sociálních reprezentací určovat centrální a okrajové elementy, které je tvoří. Podle Moscoviciho by se ale výzkumník měl zajímat rovněž o to, kde se sociální reprezentace vzaly, jedině tak je totiž může pochopit (2000). 
Jednu z cest jejich vzniku představuje vliv vědeckého poznání na společnost. V zásadě Moscovici rozlišuje tři fáze průniku vědy do každodenního myšlení: (1) vědecká fáze, ve které dochází k tvorbě nového konceptu či teorie; (2) reprezentační fáze, během které se nový poznatek šiřrí do společnosti a vznikají sociální reprezentace; (3) ideologická fáze, během které se reprezentace zmocňuje nějaká skupina lidí či instituce a prosazuje ji ve jménu vědy (Moscovici, 1984, in Plichtová, 1998, s. 505).

Pro tuto práci jsou podstatné obě oblasti - jak oblast struktury sociální reprezentace u vyučujících jako představitelů zkušenostně zakotveného každodenního, laického myšlení, tak rovněž identifikace teoretického rámce, ze kterého je sociální reprezentace vyhoření odvozena.

\section{Cíle a výzkumné otázky}

Hlavním cílem výzkumu je zjistit odpověd' na otázku, zda a jakým způsobem se liší vyhoření jakožto sociální reprezentace (pohled vyučujících) a vyhoření jakožto analytická kategorie (akademický diskurz).

Dílčí výzkumné otázky, které je potřeba vyřešit, abychom mohli na výše položenou otázku odpovědět, jsou následující:

1. Existuje statisticky významný vztah mezi subjektivním hodnocením vyhoření a měřenou mírou vyhoření?

2. Jaká je struktura sociální reprezentace vyhoření u vyučujících?

3. Liší se podoba sociální reprezentace vyhoření u vyučujících, kteří mají aktuální zkušenost s vyhořením, a u těch, kteří se aktuálně jako vyhořelí nejeví?

4. Jaký je obsah teoretických konceptů vyhoření?

V rámci otázky 1 se pokusíme odpovědět na to, zda existuje vztah mezi sociální reprezentací vyhoření a vědeckým konceptem vyhoření. Pomocí otázek 2, 3 a 4 se pokusíme nalézt konkrétní obsahy jednotlivých reprezentací/konceptů. Tím si připravíme prostor pro následné porovnání, které nám umožní zodpovědět hlavní výzkumnou otázku. 


\section{Sběr dat a metody}

Zde prezentovaná studie je součástí rozsáhlejšího výzkumu, který se zabýval syndromem vyhoření mezi vyučujícími na základních školách (Smetáčková et al., v tisku).

\subsection{Zdroje dat}

Zdrojem dat pro zkoumání kvantitativních vztahů mezi subjektivním hodnocením vyhoření a měřenou mírou vyhoření jsou výsledky dotazníku. Dotazník zahrnoval škálu vyhoření (zadávána byla Shirom-Melamedova škála vyhoření - $\mathrm{SMBM}^{4}$ ) a dotaz na subjektivní pocit vyhoření. ${ }^{5}$ Tato data byla rovněž využívána při výběru vhodných kandidátů pro rozhovor.

Zdrojem dat pro zkoumání kvalitativních obsahů sociálních reprezentací vyhoření u vyučujících jsou polostrukturované rozhovory. $V$ rámci rozhovorů jsme volily taková témata, abychom co nejkomplexněji postihly všechny stránky školy, které mohou mít vliv na profesní spokojenost a vyhoření (vztahy se žáky, s rodiči, sociální opora mezi kolegy, vedení školy, profesní historie zaměřená na př́padnou genezi syndromu vyhoření či boj s ním, soukromí, volný čas a zdroje uvolnění).

V poslední řadě využíváme položky nejpoužívanějších škál vyhoření (MBI, OLBI, CBI a SMBM). ${ }^{6}$ Ty se staly zdrojem dat pro zkoumání teoretických konceptů vyhoření.

\subsection{Participanti}

Dotazníkového šetření se zúčastnilo celkem 2394 vyučujících. Délka praxe vyučujících variovala od 0 do 49 let, přičemž průměrná délka byla 21,4 roku $(S D=10,7)$. Celková míra vyhoření měřená SMBM byla na hranici mezi velmi mírnými a mírnými projevy vyhoření. Projevy vyhoření absentovaly u $16 \%$ (podrobněji viz Smetáčková et al., v tisku). Se 46 vyučujícími byly následně provedeny rozhovory. Výběr vhodných kandidátů pro rozhovor byl dvoukrokový. Nejprve proběhl pomocí samovýběru výběr škol. Celkem jsme takto získaly k užší spolupráci 12 škol (5 škol z velkých měst, 3 školy ze středně

4 Škála SMBM (Shirom \& Melamed, 2006) byla zvolena kvůli existující české standardizaci (viz Ptáček et al., 2017).

5 Dotazník obsahoval ještě řadu dalších oblastí, zde je však neuvádíme, jelikož s nimi v tomto textu blíže nepracujeme.

6 Škály jsou podrobněji popsány ve výsledkové části. 
velkých měst, 2 školy z malých měst a 2 školy $\mathrm{z}$ vesnic). $Z$ každé školy byli o vyplnění dotazníku požádáni všichni vyučující (viz výše). Následně na základě celkového skóru v SMBM byli s žádostí o rozhovor osloveni z každé školy dva vyučující s nejnižším a dva s nejvyšším skórem v SMBM. Pokud s rozhovorem nesouhlasili, postupně byli oslovováni další vyučující v pořadí. Takto jsme získali dvě kategorie vyučujících. První kategorie vyučujících je tvořena těmi, kteří na svých školách v SMBM skórovali nízko. Druhá kategorie je naopak tvořena těmi, kteří na svých školách skórovali vysoko. I přes velké riziko nežádoucích konotací s danými pojmy byla ze stylistických důvodů první kategorie vyučujících nazvána „spokojení“ (tedy ti, kteří $\mathrm{s}$ vyhořením aktuálně nemají subjektivní zkušenost; při prezentaci výroků je značíme „sp“) a druhá „vyhořelí“ (tedy ti, kteří s vyhořením mají aktuální subjektivní zkušenost; při prezentaci výroků je značíme „vyh“), ve všech př́ípadech se ovšem jedná o analytické kategorie.

\subsection{Zpracování dat}

Prezentovaný výzkum měl čtyři fáze práce s daty. V první fázi výzkumu jsme zpracovaly kvantitativní data s cílem zjistit základní vztah mezi subjektivní a měřenou mírou vyhoření (oddíl 4.1.; odpověd' na první dílčí výzkumnou otázku).

$\mathrm{V}$ druhé fázi proběhla analýza rozhovorů. $\mathrm{V}$ rámci ní jsme vyhledaly všechny výroky, $\mathrm{v}$ nichž respondenti a respondentky popisovali vyhoření nebo vyhořelého člověka, tedy všechny výroky postihující sociální reprezentace vyhoření (celkem se jednalo o 145 výroků). Tyto výroky byly dále analyzovány prostřednictvím tematické analýzy (Plichtová, 1996; Braun \& Clarke, 2006). Při kódování výroků jsme využily postupy a techniky metody zakotvené teorie, konkrétně otevřeného kódování a axiálního kódování. Postupně jsme vyhledávaly spojitosti $\mathrm{v}$ datech mezi jednotlivými kódy a spojovaly kategorie prvního řádu, jež v této fázi vznikly, do širších celků. Tento proces vyústil v tvorbu čtyř tematických oblastí, jež v různých kontextech postihují obsah sociální reprezentace vyhoření $v$ učitelské zkušenosti. $Z$ těchto čtyř tematických oblastí (dílčích modelů vyhoření) vznikl obecný model vyhoření, založený na podhledu vyučujících (oddíl 4.2 a 4.3; odpověd' na druhou a třetí dílčí výzkumnou otázku).

V třetí fázi výzkumu jsme se zaměřily na vyhoření jakožto analytickou kategorii. Prostřednictvím čtyř tematických oblastí, jež vzešly z první fáze výzkumu, jsme analyzovaly položky nejpoužívanějších škál vyhoření (MBI, OLBI, 
CBI a SMBM) ${ }^{7}$ a identifikovaly jejich obsahovou spojitost s vytvořeným modelem. ${ }^{8}$ Porovnávaly jsme, jak se liší sycení jednotlivých oblastí položkami $\mathrm{v}$ dotazníku, např́klad v jakém rozsahu se jednotlivé dotazníky věnují daným oblastem. Položky vybraných dotazníků se tak staly dalším zdrojem analyzovaných dat (oddíl 4.4; odpověd' na čtvrtou dílčí výzkumnou otázku).

V poslední fázi výzkumu jsme provedly porovnání modelu vyhoření z pohledu vyučujících s obsahem dotazníků. Tímto srovnáním jsme se konečně dostaly k odpovědi na naši hlavní výzkumnou otázku, kterou prezentujeme $\mathrm{v}$ rámci diskuzní části.

\section{$4 \quad$ Výsledky}

\subsection{Vztah mezi subjektivní mírou vyhoření a měřenou mírou vyhoření (kvantitativní výsledky)}

Při snaze o získání odpovědi na naši základní otázku, tedy na to, zda a jakým způsobem se liší vyhoření jakožto sociální reprezentace a vyhoření jakožto analytická kategorie, jsme nejprve využily kvantitativní data. Tato data nám dobře posloužila jako odrazový můstek pro naše další bádání. Poskytla nám totiž základní informaci ohledně vztahu mezi vědeckým konceptem vyhoření (v našem případě výsledkem škály SMBM) a sociální reprezentací vyhoření (odpověd' na otázku, zda se vyučující cítí vyhořelí, je totiž na sociální reprezentaci vyhoření založená).

V následující tabulce (tabulka 1) jsou v levém sloupci uvedeny kategorie ze čtyřbodové škály, pomocí které vyučující odpovídali na otázku, zda se cítí vyhořelí. $\mathrm{V}$ druhém sloupci jsou pak uvedeny počty těch, kteří danou variantu zvolili. Ve třetím sloupci je uveden aritmetický průměr získaného skóru v SMBM pro vyučující, kteří odpověděli pomocí dané kategorie. Tak např. celkem 394 vyučujících uvedlo, že se rozhodně cítí vyhořelí (kategorie „rozhodně ano"). Průměrný skór těchto respondentů v SMBM byl 54,80. V posledním sloupci je pak uvedena směrodatná odchylka skóru umožňující zachytit variabilitu průměrného skóru dotyčných vyučujících.

\footnotetext{
Škály jsou podrobněji popsány ve výsledkové části.

8 V tomto bodě jsme konzultovali porozumění obsahu položek a jejich zařazení do zmíněných tematických oblastí s kolegyněmi a kolegy z týmu, abychom ověřili shodu na procesu analýzy dříve, než přikročíme k interpretaci jejich výsledků.
} 
Tabulka 1

Vztah mezi subjektivním hodnocením a skórem v SMBM

\begin{tabular}{llll}
\hline & Počet vyučujících & Průměrný skór SMBM & Směrodatná odchylka \\
\hline Rozhodně ano & 394 & 54,80 & 12,18 \\
Spíše ano & 750 & 46,10 & 11,12 \\
Rozhodně ne & 213 & 24,95 & 7,83 \\
Spíše ne & 786 & 33,90 & 9,17 \\
\hline Nevím & 247 & 38,06 & 9,78 \\
Nevím, co pojem & & & \\
znamená & 2 & 63,00 & 28,00 \\
Celkem & 2392 & 40,88 & 13,67 \\
\hline
\end{tabular}

Souvislost mezi subjektivním hodnocením (odpověd' na otázku, zda se cítí vyhořelí) a skórem SMBM je z tabulky na první pohled patrná. Jinými slovy, nejníže v SMBM skórovali ti, kteří se subjektivně vyhořelí necítí, a nejvýše ti, kteří se subjektivně vyhořelí cítí. Významný vztah byl potvrzen rovněž pomocí statistické analýzy $(r=0,67)$.

I přes tento zřejmý vztah bylo zajímavé se vzhledem $\mathrm{k}$ výše položeným otázkám zaměřit na vyučující, kteří subjektivně odpověděli výrazně jinak, než jak skórovali v SMBM. Z celkového počtu 2392 vyučujících, kteří dotazník vyplnili, jich 2143 odpovědělo jinak než „nevím“, respektive „nevím, co pojem znamená“. Tyto vyučující jsme seřadily dle skórů získaných v SMBM (od nejnižšího dosaženého skóru po nejvyšší dosažený skór) a následně rozdělily na 4 kvadranty tak, že v 1 . kvadrantu byli vyučující s nejnižšími skóry a ve 4 . kvadrantu vyučující s nejvyššími skóry. Následně jsme se podívaly na to, jak vyučující z jednotlivých kvadrantů odpovídali na otázku, zda se cítí vyhořelí. Výsledky jsou uvedeny v tabulce 2 .

Tabulka 2

Počty vyučujících v jednotlivých kvadrantech SMBM ve vztahu $k$ subjektivnímu hodnocení vyhoření

\begin{tabular}{lllll}
\hline & 1. kvadrant & 2. kvadrant & 3. kvadrant & 4. kvadrant \\
\hline Rozhodně ano & 11 & 35 & 79 & $\mathbf{2 6 9}$ \\
\hline Spíše ano & 72 & 142 & $\mathbf{2 6 1}$ & 275 \\
\hline Spíše ne & 294 & $\mathbf{2 8 8}$ & 171 & 33 \\
\hline Rozhodně ne & $\mathbf{1 6 1}$ & 42 & 9 & 1 \\
\hline Nevím / Nevím, co pojem znamená & 57 & 88 & 76 & 26 \\
\hline
\end{tabular}


Tučně jsou uvedeny počty těch, jejichž subjektivní hodnocení bylo zcela v překryvu se skórem v SMBM (např. odpověd' "rozhodně ne“ a zařazení do 1 . kvadrantu). S šedým podbarvením jsou pak uvedeny počty těch, jejichž subjektivní hodnocení se výrazně lišilo od skóru v SMBM (za výraznou odlišnost je považován rozdíl ve 2 až 3 stupních; např. v 1 . kvadrantu, kam byli zařazeni vyučující s nejnižším skórem v SMBM, se jedná o odpovědi na otázku Cítíte se vyhořelý/á? „spíše ano“ a „rozhodně ano“). Takových vyučujících bylo v našem vzorku celkem 161, resp. 7 \%. Lze tedy říci, že pro $93 \%$ vyučujících je zřejmě sociální reprezentace vyhoření v určitém překryvu $s$ vědeckým konceptem vyhoření. $Z$ tabulky je však dále patrné, že počty vyučujících, jejichž subjektivní hodnocení se výrazně lišilo od skóru v SMBM, nejsou rovnoměrně rozložené. U vyučujících s nejvyššími skóry v SMBM (3. a 4. kvadrant) je takovýchto vyučujících výrazně méně (43 z 1098, tj. 4 \%) než u vyučujících s nejnižšími skóry v SMBM $(118$ z 1045, tj. 11 \%).

Z kvantitativních výsledků je patrné, že existuje silný vztah mezi sociální reprezentací vyhoření a vědeckým konceptem vyhoření. Mohly bychom takto skončit a tvrdit že, mezi praxí a vědou existuje překryv. Domníváme se však, že je potřeba jít dál. Zajímá nás totiž, jakými konkrétními obsahy je tento vztah naplněn, respektive na jakých prvcích jádra pojmu je silná shoda a na jakých shoda menší. To jsou otázky, na které nám může odpovědět kvalitativní analýza.

Kvantitativní analýza dále naznačila, že vztah mezi sociální reprezentací a vědeckým konceptem je silnější u vyučujících s vyššími skóry v SMBM nežli u vyučujících s nižšími skóry v SMBM. Tato skutečnost nám potvrdila, že má smysl se dále kvalitativně zabývat rovněž otázkou rozdílu sociálních reprezentací vyhoření u vyučujících s různou mírou subjektivní zkušenosti (oddíl 4.3).

\subsection{Vyhoření jakožto sociální reprezentace}

$\mathrm{Z}$ předchozí části vyplynulo, že lze obecně uvažovat o velkém překryvu mezi vědeckým pojmem a sociální reprezentací vyhoření. $V$ této a následující části se pokusíme odpovědět na otázku, jaký je konkrétní obsah vyhoření jakožto sociální reprezentace.

V odpovědi na otázku, jak vyhoření vypadá (či jak vypadá vyhořelý učitel), ${ }^{9}$ vyučující sahali zhruba $\mathrm{v}$ polovině případů $\mathrm{k}$ obecnějším popisům, tzn. že

9 Otázky nebyly předem jednoznačně dané, ale vycházely z toho, jak se daný rozhovor vyvíjel. V některých případech byly konkrétnější: „Setkala jste se s někým, kdo by byl vyhořelý?“, 
i při konkrétním dotazu na někoho vyhořelého mluvili o „člověku“, „lidech“ či „učitelích“. V konkrétnější rovině pak hovořili bud' přímo o své vlastní zkušenosti, nebo o zkušenosti nějakého svého konkrétního kolegy.

Při analýze výpovědí vyučujících byly identifikovány čtyři kategorie symptomů, které vyučující s vyhořením spojovali. Jedná se o (1) nedostatek energie, (2) ztrátu zájmu, (3) sníženou výkonnost a (4) narušené prožívání. Jednotliví vyučující se pak lišili v tom, které kategorie akcentovali a jakým způsobem uvažovali o vzájemných vztazích mezi nimi. V následujícím textu bude nejprve prezentován obecný model vyhoření z pohledu vyučujících tak, jak vzešel z naší analýzy, a následně bude uveden podrobnější popis jednotlivých dílčích modelů.

\section{Obecný model vyhoření z pohledu vyučujících}

$\mathrm{Na}$ úvod je třeba podotknout, že obecný model vyhoření vznikl na základě syntézy dílčích modelů vyhoření, které budou pojednány dále, a je tedy do jisté míry zjednodušující. Dobře nám však poslouží jako základní model pro orientaci v tom, jak vyučující o vyhoření uvažují.

V rámci analýzy výpovědí, které se vztahovaly k problematice pojetí vyhoření, byly identifikovány 4 tematické oblasti, které vyučující s vyhořením spojovali. Ukázalo se, že mezi nimi existují různé vztahy, které jsou naznačeny na následujícím obrázku (obrázek 1). Podrobný popis tematických oblastí, jež se staly dílčími modely, bude uveden v následujícím textu.

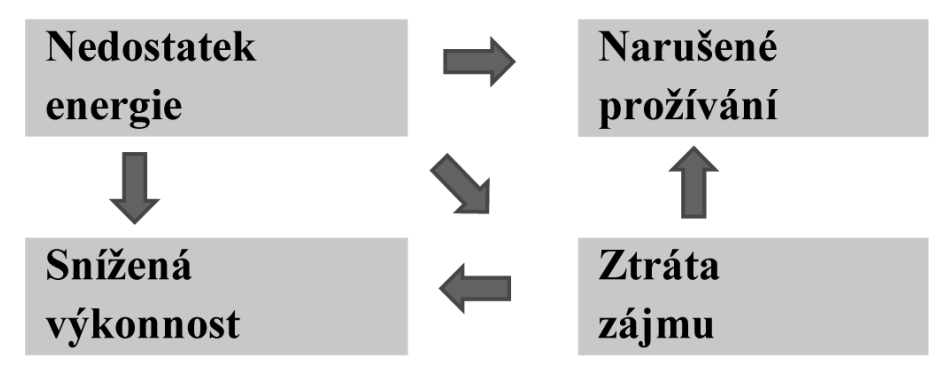

Obrázek 1. Obecný model vyhoření dle vyučujících.

případně i třeba: „Vy jste psala, že se cítíte ohrožená vyhořením. Cítíte se opravdu vyhořelá?“ nebo obecnější: „Otázka ještě přímo k tomu vyhoření, máte pocit, že je to ve školství jako nějaký reálný problém?“. V zásadě šlo ale vždy o to vyzvat vyučujícího k tomu, aby popsal svůj pohled na vyhoření nebo svoji zkušenost s ním. 
Výchozím bodem $\mathrm{v}$ rámci obecného modelu je tematická oblast nedostatek energie. Za výchozí ji považujeme ze dvou důvodů. Jedná se totiž o oblast se zdaleka největším objemem citací (cekem se o ní zmiňovalo 23 vyučujících) Současně byla některými vyučujícími identifikována jako téměř organická charakteristika profese samotné, respektive hlavní atribut učitelské práce. V následující ukázce dává učitelka únavu do souvislosti s neustálým kontaktem s lidmi:

Máme tendenci si to uplně nehlídat, protože ta interakce je velice zajímavá, že jo $\mathrm{s}$ těma lidma, čili člověk jako vstoupí do tý interakce, má pocit že ho to zároveň i nabíjí a že to prostě jako velice zajímavá věc ale pak najednou vlastně to vyučování skončí a člověk cítí, že tomu dal hodně, že tomu dal opravdu hodně, no a potom se může stát, že to udělá parkrát za sebou takhle a že je opravdu těžký už tu energii dobít tak, aby prostě ta únava tam nebyla, potom vlastně jako stěžejní pocit... (Vyh)

Jedná se tu o paradoxní charakteristiku učitelské profese; o interaktivnost, která nabíjí a současně vyčerpává. Nedostatek energie je úzce propojen s dalšími oblastmi, jež učitelé tematizují. Může se stát příčinou snížení výkonnosti (o které hovořilo celkem 13 vyučujících), narušovat vztahy (15 vyučujících) a postupně může způsobovat ztrátu zájmu (17 vyučujících). Ztráta zájmu pak může mít zpětně vliv na snížení výkonnosti a současně narušovat vztahy.

\section{(1) Vyhoření jako nedostatek energie}

Pro některé vyučující je samotný nedostatek energie totožný s vyhořením. ${ }^{10}$ Svoji vzpomínku na vyhořelého učitele popisuje paní učitelka takto: Ten člověk je už na první pohled jako bez energie. Myslím, že opravdu mu schází ta energie i normálně v kontaktu třeba s dospělýma. (Sp). Kromě nedostatku energie jako takové, který se v uvedeném pohledu kryje s vyhořením, se učitelka zmiňuje rovněž o tom, že chybějící energie zasahuje různé činnosti učitelské práce. Nejde jenom kupř́ikladu o to, že by vyhořelému učiteli chyběla energie na výuku, ale nedostává se mu jí ani např. ve zmiňovaném kontaktu s dospělými. Zdá se, že je na energii nahlíženo jako na jednolitý celek, který je třeba rozdělit mezi učitelovy jednotlivé povinnosti. Z ukázky však není zřejmé, zda jsou dospělými myšleny pouze osoby z pracovního prostředí, nebo i osoby ze soukromého života. Nedozvídáme se, jestli učitelkou zmiňovaná energie je určena pouze pro oblast pracovních povinností, nebo zda ji je

10 Otázkou však pochopitelně zůstává, zda takto vyhoření opravdu nahlížejí, nebo je pro ně únava pouze společensky přijatelnější alternativou vyhoření. 
třeba rozdělit i mezi povinnosti osobního rázu. Spíše se však zdá, že chybějící energie má tendenci zasahovat všechny oblasti. Alespoň tak je tomu ve výroku následující respondentky:

Vyh: Někdy mívám pocit, že už nevstanu, že už nemůžu. Nemám sílu vstát, večer uložit děti.

Výzk: Že se cítíte vyčerpaná?

Vyh: No, ale ne jenom fyzicky. Mám někdy pocit, že ty životní síly nemám z čeho vzít.

Zde je představa jednoho celku energie zcela explicitní. Učitelka rovněž zmiňuje nutnost dočerpávání odebrané energie. Navozovalo by to tedy představu, že je možné energii dodávat i z jiného zdroje, než kde je následně uplatňována. Zdá se, že v pojetí vyučujících není vyhoření situováno pouze do oblasti pracovní sféry, ale že dochází k jeho prolínání s osobním životem. U dané učitelky je ještě potřeba zdůraznit, že se nejedná pouze o fyzické vyčerpání. Podobný moment se objevil i u další učitelky:

Výzk: Fyzická únava?

Vyh: Jo, ale i psychická, si řikám, jestli jako mi to za to stojí, co všechno musim todle, ted' řikám, musím dát přednost tomu, nebo tomu, jako rozhodovat, co je pro mě ted' důležitý, do kdy všechno splnit, abych všechno měla. Vedu si jeden kalendář, druhej, abych nic nezapomněla. Někdy člověk je fakt vyčerpanej, že mně třeba... Vydržim pracovat dlouho... Já jsem fakt někdy jela tak, že se třeba věnuju rodině do pěti, šesti, pak sednu prostě na školu a vydržim třeba do půlnoci, do jedenácti pracovat, jo. Takhle jsem jela a v pět jsem vstávala a moc jsem nenaspala a zase se jelo.

Výpověd' učitelky navozuje představu jedoucího vlaku, který nikdy nezastaví. Neustále rostoucí povinnosti pak vyhořelý učitel dokáže splnit jen za cenu obrovského fyzického a zejména psychického úsilí. Respondentka se zmiňuje rovněž o nutnosti uspořádat priority, ovšem bez otevřené možnosti, že by některé povinnosti mohly zůstat nesplněny. Právě vysoká míra perfekcionismu byla některými vyučujícími zmiňována jako jeden z možných zdrojů vyhoření. Mohlo by se zdát nelogické, že vyučující současně jako další častou charakteristiku vyhořelých učitelů zmiňují odbývání práce (viz model 3), avšak nelogičnost je pouze zdánlivá. Je pravděpodobné, že přetíženost některých vyhořelých učitelů (a nezáleží na tom, zda se jedná o přetíženost objektivně doložitelnou, či zda jde o subjektivní pohled) může vést k odbývání práce či vyhýbání se povinnostem, které plodí další zátěž. 
(2) Vyhoření jako ztráta zájmu

Někteří vyučující akcentovali v otázce vyhoření téma ztráty zájmu. Tento dílčí model je dynamičtější; jeho předpokladem je skutečnost, že zájem o práci zde v minulosti byl, ale postupně se vytratil. Pojetí některých vyučujících je jednodimenzionální - jinými slovy samotná ztráta zájmu je vyučujícími nahlížena jako vyhoření. Jiní vyučující ovšem na ztrátu zájmu nahlížejí z hlediska prŕčinného - ztráta zájmu je pro ně důsledkem nedostatku energie: Ale můžou už tím být unavení, že je to nebaví, prijidou do určitýho stádia, že je opravdu ta práce nebaví... (Sp). Pro učitele, kteří tematizují ztrátu zájmu, je únava jakýmsi předstupněm vyhoření, jako je tomu u následujícího učitele:

Já bych řek, že jako když je člověk unavenej, tak to neni takový, jako když je uplně vyhořelej; ten psychickej stav tam jako pocituju, že je jakoby že ten člověk je na tom ještě hưr̆, jo, že třeba nemá jakoby vůbec chut' do něčeho. (Sp)

Z obsahového hlediska pak v našich datech lze rozlišit tři roviny ztráty zájmu. První z nich je ztráta zájmu o zkoušení nových věcí (nejčastěji nových aktivit či projektů). Druhá rovina je postupnou ztrátou zájmu o samotnou povahu učitelské práce (ztráta zájmu o děti či o výuku). Třetí rovinou je pak ztráta zájmu v absolutním slova smyslu - o cokoli.

\section{Nezájem o nové}

Vyhoření $\mathrm{s}$ sebou $\mathrm{v}$ reprezentacích některých učitelů přináší ztrátu zájmu o nové věci. Když tam ten člověk vstupuje už jako bez nějakýho zájmu, bez chuti něco zkoušet, jede v nějakejch zajetých stereotypech, který má jako za ty léta nějaký ověrený, ale určitě hưr ty děti nějak zaujme (Sp). Kromě zmíněné ztráty zájmu o zkoušení nového upozorňuje respondentka i na skutečnost, že ztráta zájmu není ohrožením jen pro prožívání vyučujícího, kterého se to týká, ale může se rovněž přenést na učitelovy žáky, tedy do celkové neúspěšnosti výukového procesu.

\section{Nezájem o pedagogickou práci}

Za další rovinu postupné ztráty zájmu by bylo možné považovat stav, kdy vyučující nebaví samotná práce:

Tam si myslim, že ten člověk je prostě votrávenej z tý práce, nadává si na všechno, nemá z toho vůbec radost, je to takový, že sem chodí nerad, jako že se mu sem jako doopravdy vůbec nechce, že se musí přemlouvat. (Vyh) 
V podobném duchu se vyjadřovalo i mnoho dalších vyučujících, a to jak těch, kteří s danou situací mají vlastní zkušenost, tak i těch, kteří jsou danému stavu dle svých slov vzdáleni. To je př́ípad jiné učitelky, která uvádí rovněž svoji domněnku, že ztráta zájmu je důsledkem únavy. Já nevím, já se do toho nemůžu ani vžít, ale můžou už tím být unavení, že je to nebaví, přijdou do určitýho stádia, že je opravdu ta práce nebaví. (Sp). Někteří vyučující hovořili o ztrátě zájmu o práci v obecné rovině, jiní byli konkrétnější. Nejčastěji byli předmětem ztraceného zájmu žáci. Za vyhořelého je považován takový učitel, jehož žáci přestali zajímat. V citaci následující respondentky je pak jasně vidět, že pro ni je vyhoření stav, který je mnohem závažnější než únava nebo třeba i než deprese:

Musim říct že jsem asi nezažila takovýho člověka, že to asi vopravdu ne, že jako znám lidi, který jsou opravdu hodně unavený, a řikám včetně sebe, že du až do ňákejch tak jako stavů, kdy prostě si jako si řikaj a já jsem $\mathrm{k}$ ničemu a nejde mi to, anebo do depresí a takových jako stavů jako proti sobě až jako, ale že by je nebavily ty děti, to jsem ňák jako nezažila. (Vyh)

Z ukázky je jasně patrné, že s vyhořením učitelka spojuje až takový stav, který by jednoznačně narušil základní esenci učitelství, jíž je podle ní vztah $\mathrm{k}$ dětem. Znamená vlastně ztrátu nejvlastnějšího raison d'etre pedagogické profese.

\section{Absolutní ztráta zájmu}

V poslední rovině pak dle vyučujících nejde pouze o ztrátu zájmu o oblast pracovního života, ale o ztrátu zájmu o cokoli: Třeba mám takový dojem, že člověk, který tímto projde, tak nemá chut' na nic vůbec. (Vyh). Dalo by se uvažovat tak, že vyučující tuto fázi zaměňují či překrývají s konceptem deprese, která se prolíná všemi oblastmi jejich života. ${ }^{11}$

11 Vyhoření a depresivita jsou úzce spojené. To jsme předpokládali i v našem výzkumu, a proto byl mezi výzkumné metody zahrnut dotazník měřicí depresivitu (BDI II). Mezi výsledky škály SMBM a BDI II byla nalezena vysoká korelace. Dále se ovšem ukázalo, že depresivita je vždy spojena s vyhořením, ale vyhoření s depresivitou nikoli. Jinými slovy ti, kteří jsou depresivní, jsou vyhořelí, ale ne všichni vyhořelí jsou depresivní (podrobněji bude tato problematika diskutována $\mathrm{v}$ připravovaném samostatném článku). 


\section{(3) Vyhoření jako snížení výkonnosti}

Dalším aspektem, o kterém se vyučující v souvislosti s vyhořením zmiňovali, je tendence k zanedbávání práce, respektive sklon vyhýbat se jakékoliv další práci nad rámec vlastní výuky. Tento aspekt byl zmiňován bud' samostatně, nebo $\mathrm{v}$ kombinaci s nedostatkem energie, respektive se ztrátou zájmu, a to v tom smyslu, že snížení výkonnosti je jejich důsledkem.

Snížení výkonnosti se může projevit ve více oblastech. Jedna z respondentek uvádí neřešení výchovných obtíží, které je součástí její představy o vyhořelém učiteli:

Myslím si, že se vyhýbá i řešení nějakých situací, i třeba obtížnějších, jak mezi dětma, tak i s rodičema... Ty situace jakoby radši nevidí. (Sp)

Jiná učitelka zase poukazuje na celkovou pasivitu vyhořelých učitelů v kontextu učitelské porady:

To jsou podle mě vyhořelí učitelé, kteří sedí, a i kdyby k tomu měli něco říct, tak stejně nic neřeknou. Odtrpěj. Dívaj se na hodinky a nedej bože, kdybys mluvila o něčem dýl, když už mohli jít domu. (Vyh)

Velmi výmluvně působí výraz „odtrpěj“, který učitelka použila - jakoby i sama představa další práce či aktivity vyhořelému učiteli způsobovala bolest. Zajímavé je také, že zmiňovaná pasivita je paní učitelkou nahlížena v rovině chování, $\mathrm{v}$ rovině myšlení je zpochybněna (i kdyby $\mathrm{k}$ tomu měli něco říct) a v rovině emocí se pak o pasivitu zdaleka nejedná („odtrpěj“). Zmínky týkající se problematického postoje $\mathrm{k}$ práci byly velmi časté. Často obsahovaly také téma nezájmu o děti, nikdo se však nezmiňoval př́mo o tom, že by učitelé neučili. Vyučující to zřejmě vnímají tak, že to je definiční podstata jejich povolání, bez níž už by nebylo možné hovořit o učiteli. Tak je tomu i v citaci učitelky, která upozorňuje na to, že i vyhořelý učitel učí, nicméně jeho vztah k žákủm je narušen: Že cítí povinnost, že má učit, protože chodí do práce a je učitel, takže on si odučí, ale já to cítím tak, že jestli učí děti, nebo tam učí figur$k y$, to je to stejné. (Sp). Objevily se však i výroky, podle nichž si vyhořelý učitel zjednodušuje výuku (ulehčuje si práci) až na samou hranu. Takto odpovídá jedna z respondentek na otázku, jak si představuje vyhořelého učitele:

Třeba by chodil na poslední chvíli do práce. Žádný př́pravy, asi by učil přesně to, co má podle učebnice. Asi by moc neřešil, kolik kdo má známek, napsat test, aby se jednou za čas splnilo, nejlépe test, který si děti mohou opravit samy, tak třeba zaškrtávání, asi by neměl sílu nic dělat navíc, asi by se třeba nezapojoval do projektů. (Sp) 
Ze závěrečné části citace je patrné, že respondentka za příčinu snížené výkonnosti považuje dříve zmiňovaný nedostatek energie. Učitel učí. To je základní předpoklad, kterého se učitelé drželi. Učitel může práci odbývat a vyhýbat se práci navíc, ale musí učit. Pokud neučí, tak je to jedině proto, že je ve škole fyzicky nepř́tomný:

Já si myslim, že by třeba nebyl schopnej do tý školy vůbec přijít. To si myslim já, že prostě by se nějak sesypal, psychicky by byl na tom tak špatně, že možná by musel zůstat na neschopence, aby prostě do tý školy nemusel, nemusel tam jít. Tak já si představuju vyhořelýho. (Vyh)

\section{(4) Vyhoření jako narušení prožívání}

V souvislosti s vyhořením byly zmiňovány také emoční obtíže, které se mohou negativně promítat do vztahů s druhými lidmi. Nejprve se zaměřím na povahu emocí a následně na jejich předmět.

Nejčastější emoci, kterou vyučující v souvislosti s vyhořením zmiňovali, je možné popsat jako naštvanost. Následující respondentka definuje vyhořelého učitele takto: Asi je naštvanej. Asi se nemá z čeho radovat. (Vyh). Další prožitek, který vyučující s vyhořením spojují, je otrávenost či znechucenost: Už jsou otrávený, že si to sami znechucujou. Když si to sami znechutíte, tak to je jasný, že jo. (Sp). Důležitým prvkem je zde vlastní iniciativa učitele, který není jen pasivním př́ijemcem situací, do nichž se dostává, ale sám se aktivně podílí na přetavení zážitků do negativní podoby. To je v souladu s problematikou, o které jsme se zmiňovali v části zaměřené na nedostatek energie. Vyučující zde hovořili o pasivitě, která však zasahovala primárně oblast chování, v oblasti emocí byli vyučující naopak aktivní. Kromě naštvanosti a znechucení se vyučující zmiňovali rovněž o sklíčenosti a pocitech viny, které jsou typicky spojeny s depresí: Ale to bylo hrozný, ta už pak brečela, všechno, všechny ty nezdary, nebo si pořád brala na sebe, že to je její vina. Opravdu jsme ř́lkali, ta nemůže tohleto vydržet. (Sp). V uvedené citaci je kromě poukázání na povahu emocí rovněž zdůrazněna jejich zaměřenost. Respondentka zde zdůrazňuje problém obracení negativních emocí proti sobě samému. $V$ jiných citacích se pak setkáváme rovněž se zaměřením negativních emocí vůči jiným osobám, nejčastěji vůči dětem (někdy ale také vůči rodičům či kolegům): Řve na děti, je protivnej na děti, nic na nich nevidí dobrýho. (Sp). Současně nebyl ojedinělý názor, že právě proti dětem by negativní emoce směřovat neměly: 
Ale prostě když má člověk problémy, tak si myslim, že dětem, když se učí, tak by se to nemělo projevovat a prostě být pořád pozitivní aspoň pro ty děti. Děti hodně cítí z toho kantora, jako když učí, v jaký je náladě, jak se ráno začne. (Sp)

Vyučující s narušeným emočním prožíváním již totiž nemusí mít dostatek kapacity pro vnímání potřeb žáka: Když nejste schopna vnímat ty studijní ale vlastně i ty ostatní potřeby toho žáka. (Vyh).

\subsection{Rozdíly v sociálních reprezentacích vyhoření u vyučujících s různou mírou subjektivní zkušenosti}

V předchozím textu byl popsán obecný model sociální reprezentace vyhoření i dílčí modely, které byly identifikovány ve výpovědích vyučujících. Skupinu vyučujících lze dále rozdělit na vyučující, kteří v rámci svých škol skórovali nejvýše v dotazníku SMBM, ty nazýváme „vyhořelí", a na ty, kteří skórovali nejníže a které pracovně označujeme jako „spokojené“ (viz popis metod). $V$ této části se zaměříme na povahu rozdílů mezi těmito skupinami vyučujících. $Z$ hlediska kvantitativních rozdílů je mezi vyučujícími v sycení jednotlivých modelů reprezentace vyhoření nejmarkantnější rozdíl v modelu Vyhoření jako nedostatek energie a v modelu Vyhoření jako narušení prožívání. Vyhořelí vyučující akcentovali častěji nedostatek energie, zatímco spokojení kladli častější důraz na narušené prožívání. Prakticky chybějící výroky spokojených učitelů sytící první model jsou pravděpodobně dány skutečností, že ztráta energie může být na rozdíl od ostatních oblastí (a zejména pak od narušení prožívání, které se odráží v narušení vztahů) nejvíce skryta očím okolí. To může být způsobeno tím, že okolí více vnímá například to, že učitel křičí na děti, než to, že se cítí unavený.

Výroky, které se vážou ke zbylým dvěma dílčím modelům, byly z hlediska kvantity zastoupeny zhruba ve stejném množství. Z obsahového hlediska se však rozdíly objevily v obou oblastech. V případě modelu Vyhoření jako snížení výkonnosti byla hlavním rozdílem skutečnost, že vyhořelí učitelé udávali důvod pro tento stav. To je zřejmě podobou obranného mechanismu: uváděné důvody jsou totiž vesměs vnější, a umožňují tak jedinci jakési „vyvinění“. Nejčastěji se jednalo o stresující nedostatek času nebo o chybějící energii. Tento aspekt je dobře patrný na ukázce z rozhovoru s následující učitelkou:

Je to o tom, že jsem ve stresu. Než jsme měla děti, tak jsem byla schopná si dělat hodinu př́pravu jenom na hudebku, aby měla hlavu a patu. A ted' na to nemám hodinu, takže se připravím na to podstatný a důležitý a zbytek se tak nějak odvleče. A z toho člověk nemá takovou radost. Takže rychle stáhnete něco. Dřív jsem hodně hrála na kytaru a ted' už skoro vůbec ne. Šetřím ten čas. (Vyh) 
V případě této učitelky zřejmě postupně vzrostlo napětí mezi nároky, které na sebe klade, a tím, co je schopná aktuálně, vzhledem k rodinné situaci, do práce investovat. Toto napětí pak vede ke stresu a k negativním pocitům z práce.

V rámci modelu Vyhoření jako ztráta zájmu spokojení učitelé častěji zmiňovali ztrátu zájmu o samotnou povahu práce, zatímco mezi vyhořelými se častěji vykytuje téma celkové ztráty zájmu. Některé citace jsou pak velmi výmluvné: Jsem hrozně unavená a nemám na nic chut', ale fakt vůbec na nic, jo. (Vyh). Lze předpokládat, že tento rozpor je opět dán tím, že ti, kdo vyhoření aktuálně neprožívají, vnímají u svých kolegů a kolegyň jen nezájem o práci, a ne jejich celkový duševní stav. Dalším rozdílem, který je však s tímto spojený, je způsob, jakým vyhořelí o ztrátě zájmu hovoří. Zatímco v citacích spokojených vyučujících se objevovala spojení typu „nebaví, „nemá radost“, vyhořelí vyučující sahali častěji k výrazům spojeným se „ztrátou chuti“. A konečně posledním rozdílem mezi vyhořelými a spokojenými vyučujícími je otázka předmětu ztráty zájmu. Pouze spokojenými vyučujícími byla explicitně zmiňována ztráta zájmu o žáky. Tato skutečnost může mít dva důvody. První může souviset $s$ tím, že vyhořelí učitelé obecně méně zdůrazňovali předmět chybějícího zájmu, jelikož častěji mluvili o celkové ztrátě zájmu. Druhým důvodem, který ovšem první nevylučuje, je pak skutečnost, že v př́padě promluv týkajících se vlastní osoby je ztráta zájmu o žáky pro vyučující v jistém smyslu odhalením (profesního selhání). Z pohledu spokojených vyučujících se pak může zdát, že někteří z nich svým vyhořelým kolegům vyčítají skutečnost, že pro ně nejsou žáci na prvním místě: Když máš ty děti a chceš mít na prvním místě jako ty děti, tak oni nejsou u nich na prvním místě. (Sp). Otázkou samozřejmě zůstává, zda právě ti vyučující, kteří v minulosti měli žáky zcela na prvním místě, aktuálně neskórují jako vyhořelí a opačně, zda ti vyučující, kteří se domnívají, že by žáci měli být na prvním místě, nejsou nejvíce ohroženi vyhořením do budoucna. 0 tom, kde leží jádro ohrožení, můžeme diskutovat, avšak ztráta zájmu o děti jako taková se v našich datech ukazuje jako významná součást sociálních reprezentací vyhoření u učitelů. Jako by se jednalo o něco, co je již za hranou, co učitele degraduje a narušuje jeho učitelskou identitu.

Lze shrnout, že jádrovou vlastností vyhoření je pro vyučující, kteří nemají s vyhořením aktuální zkušenost (tzv. spokojení), ztráta identity učitele. Za vyhořelého je považován ten, kdo ztrácí základní esenci učitelství, tedy ten, pro kterého přestali být důležití žáci (ztratil o ně zájem). Př́íčiny tohoto stavu 
nejsou těmito vyučujícími většinou uváděny, a to pravděpodobně proto, že jim zůstávají skryty. Akcentována je tak zejména vnější rovina chování (narušené vztahy a snížení pracovní výkonnosti). Oproti tomu vyučující, kteří s vyhořením mají aktuální zkušenost (tzv. vyhořelí), akcentují pouze prř́činy tohoto stavu, který v jejich výpovědích bud' není (explicitně) př́tomen, nebo spíše zůstává zamlčen. Rozdíly mezi spokojenými a vyhořelými vyučujícími jsou znázorněny na následujících obrázcích (obrázek 2, obrázek 3).

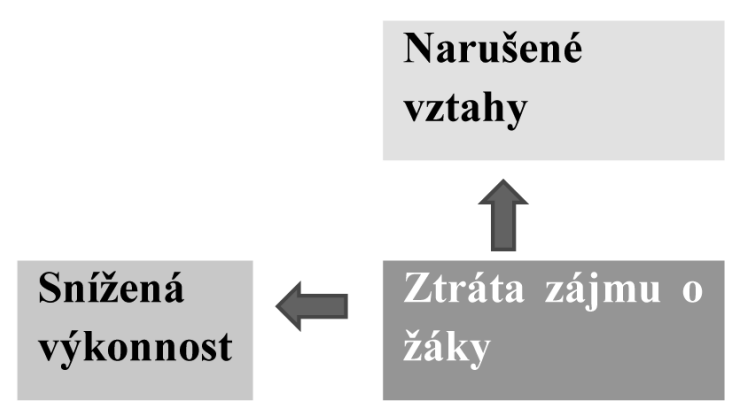

Obrázek 2. Sociální reprezentace vyhoření: spokojení.

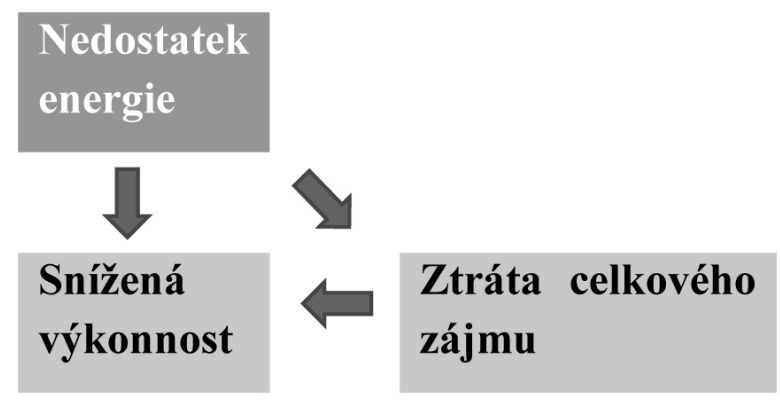

Obrázek 3. Sociální reprezentace vyhoření: vyhořelí.

\subsection{Vyhoření jakožto analytická kategorie}

Předchozí text nám pomohl odpovědět na otázku, jaký je obsah sociální reprezentace vyhoření u skupiny vyhořelých a spokojených vyučujících. V následujícím textu se pokusíme konceptualizovat vyhoření tak, jak je prezentováno $\mathrm{v}$ rámci vědeckého diskurzu. Za tímto účelem byly vybrány čtyři často používané škály vyhoření, které se ovšem liší ve svých teoretických východiscích. Jedná se o Maslach Burnout Inventory (MBI; Maslach \& Jackson, 1986), Oldenbourg Burnout Inventory (OLBI; Demerouti, Bakker, Nachreiner, 
\& Schaufeli, 2001), Copenhagen Burnout Inventory (CBI; Kristensen et al., 2005) a Shirom-Melamed Burnout Measure (SMBM; Shirom \& Melamed, 2006). V tabulce 3 je uveden stručný přehled základních charakteristik jednotlivých sledovaných škál.

Tabulka 3

Základní charakteristiky vybraných škál vyhoření

\begin{tabular}{|c|c|c|c|c|}
\hline & Rok & Definice & Dimenze & $\begin{array}{l}\text { Teoretický model } \\
\text { (vznik vyhoření) }\end{array}$ \\
\hline MBI & 1986 & $\begin{array}{l}\text { Psychologický syndrom } \\
\text { emočního vyčerpání, } \\
\text { odcizení (depersonalizace) } \\
\text { a poklesu výkonnosti } \\
\text { u lidí zaměstnaných } \\
\text { v pomáhajících profesích. }\end{array}$ & $\begin{array}{l}\text { (Emoční) } \\
\text { vyčerpání } \\
\text { Depersonalizace/ } \\
\text { cynismus } \\
\text { Pokles výkonnosti }\end{array}$ & $\begin{array}{l}\text { Důsledek dlouhodobého } \\
\text { stresu. }\end{array}$ \\
\hline OLBI & 2001 & $\begin{array}{l}\text { Vyčerpání a stažení se } \\
\text { z nároků práce. }\end{array}$ & $\begin{array}{l}\text { Vyčerpání } \\
\text { Stažení se }\end{array}$ & $\begin{array}{l}\text { Model požadavků } \\
\text { a zdrojů - vyhoření vzniká } \\
\text { tehdy, když jsou požadavky } \\
\text { vysoké a zdroje nízké. }\end{array}$ \\
\hline CBI & 2005 & $\begin{array}{l}\text { Vyčerpání a únava vázaná } \\
\text { na specifickou (pracovní) } \\
\text { oblast. }\end{array}$ & Vyčerpání & - \\
\hline SMBM & 1989 & $\begin{array}{l}\text { Individuální pocit } \\
\text { fyzického, emočního } \\
\text { a kognitivního vyčerpání } \\
\text { vycházející z chronické } \\
\text { expozice pracovnímu } \\
\text { stresu. }\end{array}$ & Vyčerpání & $\begin{array}{l}\text { Důsledek dlouhodobého } \\
\text { pracovního stresu. } \\
\text { Teorie uchování zdrojů. } \\
\text { Model požadavků } \\
\text { a kontroly - vyhoření } \\
\text { vzniká tehdy, když } \\
\text { jsou požadavky vysoké } \\
\text { a kontrola nízká. }\end{array}$ \\
\hline
\end{tabular}

Co tedy pojem vyhoření ve vědeckém diskurzu znamená? Všichni autoři se shodují, že vyhoření je vázáno na pracovní oblast a více či méně souvisí s vyčerpáním. S výjimkou MBI je vyčerpání pojímáno obecněji, ne jenom ve smyslu emočního vyčerpání. Důvodem je zřejmě mimo jiné skutečnost, že zatímco MBI je zaměřena pouze na pracovníky pomáhajících profesí, ostatní škály jsou určeny i pro jiné profese. Pro CBI a SMBM je pak vyčerpání jedinou komponentou vyhoření. OLBI navíc pracuje se stažením se, které považuje za obecnější vyjádření depersonalizace/cynismu, se kterým pracuje MBI. Jediná škála MBI pak uvádí ještě třetí komponentu vyhoření, kterou nazývá snížená pracovní výkonnost. 
Aby bylo možné jednotlivé konceptuální rámce opravdu porovnat, a zejména aby tyto rámce bylo možné porovnat se sociální reprezentací vyhoření u učitelů, je třeba učinit krok zpět a analyzovat, jakou mají jednotlivé dimenze oporu v konkrétních položkách jednotlivých dotazníků. Za účelem srovnání je však nutné nejprve utvořit vhodnou platformu, na níž bude srovnání provedeno. Jednotlivé položky škál proto byly rozřazeny do tematických oblastí, které byly definovány na základě učitelských výpovědí (nedostatek energie, ztráta zájmu, snížená výkonnost a narušené prožívání). Souhrnné výsledky jsou prezentovány v tabulce 4.

Tabulka 4

Sycení jednotlivých škál tematickými oblastmi vzešlými z rozhovorů

\begin{tabular}{lllllll}
\hline Škála & $\begin{array}{l}\text { Nedostatek } \\
\text { energie }\end{array}$ & Ztráta zájmu & $\begin{array}{l}\text { Snížená } \\
\text { výkonnost }\end{array}$ & $\begin{array}{l}\text { Narušené } \\
\text { prožívání }\end{array}$ & Nezařazeno & Celkem \\
\hline MBI & 9 & 4 & 3 & 2 & 4 & 22 \\
\hline OLBI & 6 & 8 & 2 & & & 16 \\
\hline CBI & 10 & 1 & & 1 & 7 & 19 \\
\hline SMBM & 6 & & & 3 & 5 & 14 \\
\hline Celkem & 31 & 13 & 5 & 6 & 16 & 71 \\
\hline
\end{tabular}

Z tabulky je patrné, že ve vědeckém diskurzu je vyhoření nejčastěji spojováno s nedostatkem energie. Další významnou kategorií je „oblast ztráty zájmu“. Položek spadajících do kategorií „snížená výkonnost" a „narušené prožívání" je minimum. 16 otázek z celkového počtu 71 pak nebylo zařazeno do žádné z kategorií vzniklých z rozhovorů s vyučujícími. Dále bylo sledováno, jakými učitelskými kategoriemi jsou reprezentovány dimenze jednotlivých škál. Výsledky jsou prezentovány v tabulce 5 . 
Tabulka 5

Sycení jednotlivých dimenzí tematickými oblastmi vzešlými z rozhovorů

\begin{tabular}{|c|c|c|c|c|c|c|}
\hline & $\begin{array}{l}\text { Nedostatek } \\
\text { energie }\end{array}$ & $\begin{array}{l}\text { Ztráta } \\
\text { zájmu }\end{array}$ & $\begin{array}{l}\text { Snížená } \\
\text { výkonnost }\end{array}$ & $\begin{array}{l}\text { Narušené } \\
\text { prožívání }\end{array}$ & $\begin{array}{l}\text { Nezařa- } \\
\text { zeno }\end{array}$ & Celkem \\
\hline MBI - Vyčerpání & 7 & & 1 & 1 & & 9 \\
\hline MBI - Depersonalizace & & 4 & & & 1 & 5 \\
\hline MBI - Výkonnost & 2 & & 2 & 1 & 3 & 8 \\
\hline OLBI - Vyčerpání & 6 & & 1 & & & 7 \\
\hline OLBI - Nezaujetí & & 8 & 1 & & & 9 \\
\hline CBI - Osobní vyčerpání & 4 & & & & 2 & 6 \\
\hline CBI - Pracovní vyčerpání & 4 & & & & 3 & 7 \\
\hline CBI - Klientské vyčerpání & 2 & 1 & & 1 & 2 & 6 \\
\hline SMBM - Fyzické & 3 & & & & & 3 \\
\hline SMBM - Kognitivní & & & & & 5 & 5 \\
\hline SMBM - Emoční & & & & 3 & & 3 \\
\hline
\end{tabular}

Škála MBI obsahuje tři dimenze - vyčerpání, depersonalizaci a sníženou pracovní výkonnost. Z tabulky je patrné, že „MBI - vyčerpání“ se prakticky překrývá s kategorií „nedostatek energie“. Rovněž znění jednotlivých položek rezonuje s konkrétními výroky vyučujících (např. otázka 14: Mám pocit, že plním své úkoly tak usilovně, že mne to vyčerpává.). Další dimenzí je „MBI - depersonalizace“. Zde nacházíme silný překryv s kategorií „ztráta zájmu“. Po obsahové stránce je ale překryv slabší než u předchozí kategorie. Učitelským výrokům odpovídá např. položka 15: Už mne dnes moc nezajímá, co se děje $s$ mými klienty/pacienty. Některé položky jsou ale více zaměřeny na obtíže v oblasti prožívání, týkající se obavy ze ztráty empatie (např. položka 10: Od té doby, co vykonávám svou profesi, stal jsem se méně citlivým k lidem.). Celkově je zde více akcentována neschopnost citové investice do klientů, zatímco vyučující primárně hovořili o tom, že je práce s dětmi (klienty) nebaví. Nejmenší odraz v učitelské perspektivě je patrný v pojetí dimenze „snížená pracovní výkonnost“.

Škála OLBI je tvořena dvěma dimenzemi - vyčerpáním a nezaujetím. Dle předpokladu první jmenovaná dimenze odráží kategorii „nedostatek energie“ 
a druhá „ztrátu zájmu“. Shoda s perspektivou vyučujících je patrná i ve znění konkrétních výroků, a to jak v dimenzi vyčerpání, tak rovněž v dimenzi nezaujetí. Dimenze „OLBI - nezaujetí pak mnohem více koresponduje s učitelskými výroky z kategorie „ztráta zájmu“ nežli dimenze „MBI - depersonalizace“, jelikož v OLBI je kladen větší důraz na samotný zájem o práci (např. položka 1: I always find new and interesting aspects in my work.).

Škála CBI je podle autorů jednodimenzionální, všechny výroky se váží k vyčerpání. Lze je nicméně rozdělit do tří oblastí: na osobní vyčerpání, pracovní vyčerpání a vyčerpání související s klienty. Celkově nejvíce položek opravdu spadá do oblasti „,nedostatku energie“, v oblasti vyčerpání však byla identifikována rovněž položka spadající do kategorie „ztráty zájmu“ (17: Do you feel that you give more than you get back when you work with clients?) a do kategorie „narušeného prožívání" (16: Do you find it frustrating to work with clients?). Kromě toho škála obsahuje velké množství položek (celkem 7), které nebylo možné jednoznačně přiřadit do učitelských kategorií. Nemožnost jednoznačného zařazení však nebyla dána tím, že by položky akcentovaly zcela jiné aspekty než vyučující, ale že byly příliš obecné. Např. v otázce 14: Do you find it hard to work with clients? nelze jednoznačně určit, jestli je obtížnost práce s klienty ovlivňována nedostatkem energie, ztrátou zájmu či narušeným prožíváním.

Jednodimenzionální je rovněž škála SMBM. Dělicí linka mezi jednotlivými oblastmi však není tvořena tím, jak velkou životní oblast zasahuje, ale tím, jakých aspektů jednotlivce se týká. Mluví se zde o fyzickém, kognitivním a emočním vyčerpání. Po překategorizování se však ukazuje, že škála je jednodimenzionální pouze zdánlivě, respektive že z hlediska výpovědí vyučujících lze výroky zařadit jak do kategorie „nedostatku energie“, tak rovněž do kategorie „narušeného prožívání“. Některé z výroků pak nespadají do žádné kategorie. Nejméně problematická je oblast fyzického vyčerpání, ta se zcela překrývá s kategorií „,nedostatku energie“. Rovněž na úrovni jednotlivých položek je rezonance s výroky vyučujících velmi vysoká (např. položka 2: Necítím žádnou sílu jít ráno do práce.). Jinak je tomu s oblastí „kognitivního vyčerpání", k němu nebyla z hlediska učitelské reprezentace vyhoření nalezena žádná analogie. Jde o výroky typu „Obtížně se koncentruji.“ (položka 8) či „Dělá mi potíže přemýšlet o složitých věcech." (položka 11). Oblast emočního vyčerpání je pak v souladu s učitelskou kategorií „narušené prožívání“. 
Např. položka 12: Cítím, že se mi nedaří být citlivý/á k potřebám spolupracovníků a zákazníkủ.

Můžeme shrnout, že teoretický rámec vyhoření nejčastěji akcentuje kategorii „únavy“. V této oblasti je rovněž mezi jednotlivými škálami největší shoda. Zvláště ve škále „MBI - vyčerpání" a „OLBI - vyčerpání“ je výrazný obsahový překryv. Druhou nejvýznamnější kategorií je ztráta zájmu. Ta je sycena dimenzemi „MBI - depersonalizace“ a „OLBI - nezaujetí“. Zaměřenost jednotlivých položek se ale liší. MBI směřuje více k neschopnosti citových investic, zatímco OLBI - nezaujetí se více týká chybějícího zájmu, což mnohem více koresponduje s učitelskou perspektivou.

\section{Diskuze: Vyhoření z různých perspektiv}

V rámci kvantitativní analýzy se prokázal výrazný překryv mezi subjektivní a měřenou mírou vyhoření. Z kvalitativní analýzy dále vyplynulo, že jak vědecký diskurz, tak učitelský diskurz tzv. vyhořelých učitelů akcentují ve vztahu k vyhoření zejména kategorii „chybějící energie“. Dalo by se tedy konstatovat, že chybějící energie je jádrem sociální reprezentace vyhoření. Z prezentovaných vědeckých modelů vyhoření má pojetí tzv. vyhořelých učitelů nejblíže k jednodimenzionálním modelům (SMBM, CBI), ovšem na rozdíl od nich vyučující zdůrazňovali i periferní elementy, tady důsledky vyhoření, jakými jsou dle nich pokles výkonnosti a celková ztráta zájmu. Z tohoto hlediska se tedy blíží rovněž MBI. Samotné učitelské pojetí vyčerpání je pak vzhledem k míře obecnosti nejblíže k pojetí OLBI. Únava podle respondentů zasahuje nejenom fyzickou oblast, ale i oblast psychickou, emoční. V tomto smyslu sledujeme spíše překryv se škálami, které se neomezují pouze na emoční vyčerpání. Nikdo z vyučujících totiž neakcentoval jen fyzickou únavu bez zasáhnutí dalších složek. Vyučující většinou hovořili o celkové ztrátě energie, což je v souladu pojetími - tak jak je prezentováno v rámci OLBI. Oddělení ztráty energie pouze pro oblast práce $s$ učitelskými výroky nerezonovalo. Energie je totiž v pojetí tzv. vyhořelých vyučujících spíše monolitní, a pokud chybí v pracovní oblasti, pak se její nedostatek přenáší rovněž do soukromé oblasti. Z tohoto pohledu se tedy sociální reprezentace vyučujících odlišují od CBI, která se snaží jednotlivé oblasti vyčerpání oddělovat.

Pokud bychom tedy zůstali u tohoto zjištění, můžeme konstatovat, že věda a učitelé si ve velké míře rozumí. Na problém však narazíme tehdy, když se zaměříme na to, zda si rozumí rovněž věda a vyučující, kteří s vyhořením 
aktuální subjektivní zkušenost nemají (tzv. spokojení). V rámci kvantitativní analýzy bylo ukázáno, že mezi těmito vyučujícími je téměř třikrát více těch, jejichž subjektivní hodnocení vyhoření se od toho měřeného výrazně liší. Skutečnost rozdílů mezi sociální reprezentací vyhoření a vědeckým konceptem vyhoření u spokojených vyučujících byla potvrzena rovněž kvalitativní analýzou. Ukázalo se totiž, že sociální reprezentace spokojených vyučujících je objektifikována jiným způsobem než sociální reprezentace vyhořelých vyučujících. Rozdíly byly nalezeny zejména $\mathrm{v}$ tom, že nevyhořelí vyučující na rozdíl od teorie i od vyhořelých vyučujících neakcentují kategorii „vyčerpání“, ale důraz kladou na „ztrátu zájmu o žáky“, která z jejich pohledu znamená ztrátu identity učitele.

Spokojení vyučující akcentují zejména vnější rovinu vyhoření (z určitého pohledu se zaměřují spíše na důsledky), a to proto, že vnitřní rovina (příčiny) jim zůstává skryta. Oproti tomu vyhořelí vyučující akcentují spíše vnitřní rovinu, jelikož ta vnější (zejména v oblasti zájmu o žáky a vztahu k nim) je pro ně z hlediska vlastní identity př́liš ohrožující. Zakotvenost sociální reprezentace vyhoření je tedy mezi skupinami odlišná.

Jisté nebezpečí je tedy skryto $v$ tom, že vědecký diskurz se může spolupodílet na tom, že se vzdálenost mezi pojetím vyhořelých a spokojených bude ještě více zvětšovat. To může mít za následek postupné odcizování vyučujících s různou mírou zkušenosti s vyhořením. Současně může toto vzdalování způsobovat, že nevyhořelí vyučující budou nedostatečně citliví na rozpoznávání vyhoření $v$ jeho počátcích. Tím, že se vědecký diskurz zaměřuje zejména na energetickou složku, není pro spokojené vyučující informačně obohacující, protože jejich sociální reprezentace se s vědeckým konceptem míjí. Spokojení vyučující tedy vidí stále pouze důsledky vyhoření, ale nenahlížejí jeho důvody, což může snižovat jejich schopnost empatie vůči tzv. vyhořelým kolegům. Domníváme se, že pokud by se vědecký diskurz více zaměřoval na problematiku identity učitele, mohli by z toho vyhořelí vyučující těžit ve dvou rovinách. Spokojení vyučující by díky tomu mohli vyhořelým vyučujícím lépe porozumět a současně by zdůraznění identitního problému mohlo vést $\mathrm{k}$ jeho detabuizaci. To by mohlo vyhořelým vyučujícím pomoci s vlastním sebepřijetím a zpracováním problému. 


\section{Závěr}

Náš výzkum si kladl za cíl analýzu sociálních reprezentací vyhoření u vyučujících $\mathrm{z}$ praxe a jejich porovnání $\mathrm{s}$ modely vyhoření užívanými $\mathrm{v}$ akademickém diskurzu. $\mathrm{V}$ rámci předchozího textu jsme ukázali, že i přes velký překryv aktérské a vědecké perspektivy mezi nimi existují zásadní rozdíly. Ty souvisejí zejména s odlišným zakotvením sociální reprezentace vyhoření u spokojených vyučujících.

Nezávisle na tom, z jaké pozice $\mathrm{k}$ vyhoření přistupujeme, je nesporné, že pro vyučující se jedná o reálnou zkušenost, která velmi negativně ovlivňuje mnoho aspektů jejich života a zasahuje i do života žáků, se kterými pracují. Naléhavost tohoto tématu tedy zdaleka není zdánlivá. Je nutné zabývat se perspektivou aktérů učitelské profese $\mathrm{v}$ praxi. I kdyby pro nic jiného, tak zcela jistě proto, že ve třech ze čtyř námi sledovaných škál existuje př́má otázka na to, zda se respondent cítí vyhořelý (!). Bez toho, abychom porozuměli sociální reprezentaci vyhoření u vyučujících, není možné výsledky škál interpretovat, natož porozumět fenoménu vyhoření, tak jak je tematizován $\mathrm{v}$ životě škol.

Chtěli bychom ovšem, aby byl náš text vnímán nejen jako snaha o porozumění fenoménu vyhoření ve školním prostředí, ale také jako metodologický příspěvek. Věříme, že na příkladu vyhoření byla ukázána důležitost neustálého dialektického pohybu mezi vědeckým diskurzem a sociálními reprezentacemi aktérských perspektiv. Ve vědě totiž snadno můžeme podlehnout zdání, že popisujeme realitu, ale zkušenost aktérů této reality může být zcela jiná.

\section{Literatura}

Bačová, V. (2000). Sociálny konštrukcionizmus v psychológii. Československá psychologie, 44(3), 237-246.

Braun, V., \& Clarke, V. (2006). Using thematic analysis in psychology. Qualitative Research in Psychology, 3(2), 77-101.

Demerouti, E., Bakker, A. B., Nachreiner, F., \& Schaufeli, W. B. (2001). The job demands-resources model of burnout. Journal of Applied psychology, 86(3), 499-512.

Johnson, S., Cooper, C., Cartwright, S., Donald, I., Taylor, P., \& Millet, C. (2005). The experience of work-related stress across occupations. Journal of managerial psychology, 20(2), 178-187.

Kant, I. (2001). Kritika čistého rozumu. Praha: Oikoymenh.

Kebza, V., \& Šolcová, I. (2003). Syndrom vyhoření. Praha: Státní zdravotní ústav.

Kouřilová, S. (2009). Strukturální přístup k sociálním reprezentacím. E-psychologie, 3(2), 49-58. 
Kristensen, T. S., Borritz, M., Villadsen, E., \& Christensen, K. B. (2005). The Copenhagen burnout inventory: A new tool for the assessment of burnout. Work \& Stress, 19(3), 192-207.

Marek, T., Schaufeli, W. B., \& Maslach, C. (2017). Professional burnout: Recent developments in theory and research. London: Routledge.

Maslach, C., \& Jackson, S. E. (1981). The measurement of experienced burnout. Journal of Occupational Behavior, 2, 99-113.

Maslach, C., Jackson, S. E., Leiter, M. P., Schaufeli, W. B., \& Schwab, R. L. (1986). Maslach burnout inventory. Palo Alto: Consulting Psychologists Press.

Moscovici, S. (1981). On social representations. Social cognition: Perspectives on everyday understanding, 8(12), 181-209.

Moscovici, S. (2000). The phenomen of social representations. In S. Moscovici \& G. Duveen Social representations: Explorations in social psychology (s. 18-77). Cambridge: Polity Press.

Novák, P. (2009). Teorie sociálních reprezentací. E-psychologie, 3(1), 22-29.

Plichtová, J. (1998). Sociálne reprezentácie: teória, výskum, výzva. Československá psychologie, 42(6), 503-520.

Ptáček, R., Raboch, J., Kebza, V., Šolcová, I., Vňuková, M., Hlinka, J. ... Strakatý, ک̌. (2017). Česká verze Shiromovy a Melamedovy škály vyhoření. Československá Psychologie, 61(6), 536-545.

Shirom, A., \& Melamed, S. (2006). A comparison of the construct validity of two burnout measures in two groups of professionals. International Journal of Stress Management, 13(2), 176-200.

Smetáčková, I., Viktorová, I., Štech, S., \& Ptáček, R. (v tisku). Vztah syndromu vyhoření, copingových strategií a self-efficacy mezi vyučujícími na českých základních školách. Československá psychologie.

Šimeček, M. (2008). Sociální reprezentace sexuálních deviací (Dizertační práce). Brno: Masarykova univerzita.

Urbanovska, E. (2011). Occupational teacher's stressors and burn-out syndrome. School and Health, 21, 303-317.

Vybíral, Z. (2001). Tři desetiletí kritické psychologie ve světě. Československá psychologie, 45(1), 69-81.

Židková, Z., \& Martinková, J. (2003). Psychická zátěž učitelů základních škol. České pracovní lékařství, 4, 122-126.

\section{Autorky}

PhDr. Anna Páchová, Ph.D., Univerzita Karlova v Praze, Pedagogická fakulta,

Katedra psychologie, Myslíkova 7, 11000 Praha 1, anna.pachova@pedf.cuni.cz

PhDr. Veronika Francová, Ph.D., Univerzita Karlova v Praze, Pedagogická fakulta, Katedra psychologie, Myslíkova 7, 11000 Praha 1, veronika.francova.pedf@gmail.com 


\title{
Teacher's social representations of burnout: burnout between experience and analytical category
}

\begin{abstract}
Burnout syndrome as a high risk factor for teachers is well established term in scientific and also in public discourse. But what does the term burnout syndrome actually mean? What is the relation between science and teachers themselves? To better understand it, it is necessary to deal with science on the one hand and the actors on the other.

This study therefore wants to answer the question of the differences between social representation of burnout (teacher's perspective) and burnout as an analytic category (perspective of the science). The general topic of the social representations is mentioned in the introduction, followed by the description of methods and results part. The comparison of the perspectives is in the discussion.

Our data contains questioner of burnout $(\mathrm{N}=2394)$, interviews with teachers about burnout $(\mathrm{N}=46)$ and the items of the most used measures of burnout.

The results indicate that the social representation of teachers with burnout experience overlaps scientific concept of burnout. However, the social representation of teachers without this experience does not. These teachers accentuate mainly the extrinsic level of burnout (from a certain point of view, they are more focused on the consequences) because the intrinsic level (the causes - exhaustion) remains hidden. The article is also dealing with the consequences in school reality.
\end{abstract}

Keywords: burnout, social representations, teachers, primary school 